\title{
Gadamer on Friendship and Solidarity: The Increase in Being in Communal Human Life
}

\author{
Alexandra Makurova \\ PhD Student, School of Philosophy, National Research University Higher School of Economics \\ Address: Myasnitskaya str., 20, Moscow, Russian Federation 101000 \\ E-mail: alexandra.makurova@gmail.com
}

\begin{abstract}
This article discusses Gadamer's conception of friendship as a part of his draft of a conception of practical philosophy. His starting point is Greek philosophy, specifically Plato's and Aristotle's views on friendship. He adds significant nuances to the understanding of friendship that were first laid down in his doctrine of philosophical hermeneutics. It allows him to place the notion of friendship in the context of modern philosophical debate and social criticism, and thus to make an original contribution to the discussion. Gadamer understands friendship as a necessarily reciprocal structure. He emphasizes the fact that only reciprocity or a kind of relation to someone other than "me" can serve as a sufficient basis for the explanation of the possibility of a community, as opposed to neo-Kantian and a phenomenological adherence to self-consciousness. The notion of friendship is closely connected to the notion of solidarity. The first one is considered as a more universal and thus grounding type of interpersonal communication, whereas natural solidarity is a specific kind of bond that can grow into the true friendship. Furthermore, friendship is seen as an accession of being (Zuwachs an Sein) from a teleological point of view, i.e., the true friendship is a contribution to and the realization of life. The outcome of this practice cannot be differentiated from its process.
\end{abstract}

Keywords: Gadamer, philosophical hermeneutics, friendship, solidarity, increase in being, understanding, practical philosophy

The issue of friendship cannot be considered as entirely new for social philosophy, since it was a subject of interest in Ancient Greece, and discussed in the poetic treaties of Hesiod and Homer. Friendship was the main topic of Plato's dialogue Lysis. Aristotle paid significant attention to this problem in his three works on ethics. Later, Cicero addresses it in his treatise On Friendship, while Plutarch dedicated a special treatise entitled On Having Many Friends to the question of friendship. This topic has re-appeared in recent modern philosophy. Its renaissance can be attributed to the critique of modern society, and to the pursuit of alternative ways for thinkers to consider the possible forms of society or forms of power that would be free from the necessary oppressive implementations. The names that come to mind first are those of Arendt and her discussion of friendship in The Human Condition (1958), Derrida with his book Politics of Friendship (1997), and Agamben, who wrote the essay The Friend (2007).

(C) Alexandra Makurova, 2016

(c) Centre for Fundamental Sociology, 2016

DOI: 10.17323/1728-192X-2016-4-146-161 
Among these philosophers, the name of Gadamer may sound alien. Indeed, his approach to the question of friendship is different as compared to that of Derrida. ${ }^{1}$ If the strategy of the latter can be called negation, then Gadamer's approach is better described as affirmation, or making it visible through affirmation. Why negation? Since Derrida tries to find an alternative to alread-existing power relations, i.e., he negates them and strives to suggest a strategy to overcome them by suggesting the notion of friendship to come (à venir). Gadamer, on the contrary, turns to the ever-enduring examples of positive relations that existed once, and can be found in every community of every historical epoch and culture.

It is not a common idea to see Gadamer as a thinker in the sphere of practical philosophy. However, a brief insight in his writing besides Truth and Method already provides enough evidence of his deep interest in the issues of ethics and politics throughout his long academic career. If at the beginning his engagement was more of a speculative character, it is especially noticeable how this involvement grew increasingly concrete with time in the examples of his later writings. Starting from the 1960s, his attempt to contribute to the self-understanding of society can be seen as a twofold movement. On the one hand, he openly criticizes certain aspects of it, namely, the prevalence of expert knowledge and the lack of social reflection ${ }^{2}$ which lead to the incapability of citizens to create social bonds on the basis of common interaction. Instead of trying to manage the problems on their own, they delegate this function to experts. On the other hand, he tries to make a positive contribution to the texture of common social life with his own work. It is a performative gesture of which the initial purpose is not stated explicitly, so it is the responsibility of a reader to notice it.

Thus, those who want to evaluate Gadamer's position may fall into a contradiction. Although Gadamer wrote about some politically relevant topics and suggested an original interpretation of friendship, solidarity, and ethics on the whole, it would still be inconsistent to label him as a political thinker. He did not strive to achieve the level of an expert. Rather, his contributions were and should be regarded as performative attempts to bring to life that which was at the same time the subject matter of his theoretical considerations. This may be particularly clear in the case of his reasoning about friendship and solidarity.

Both topics are regarded in their relevance for the contemporary situation, characterized by the philosopher as a lack of natural solidarity. However, as opposed to the critique of the Frankfurt School directed to the very grounds of modern culture, for example, Gadamer's skepticism is not so pervasive. He does not draw a fixed border between authentic and inauthentic forms of cooperation, and still assumes the possibility of demonstra-

1. For a more detailed comparison of the two authors, see Caputo, 2002. According to Caputo, Derrida tries to escape the necessity of any grounding politics on friendship, whereas Gadamer remains close to the metaphysical tradition. Caputo ascribes certain essentialism to Gadamer. However, as it will be shown, Gadamer himself emphasized the specific character of friendship as a relationship that can never be completely fulfilled. So, it is worth noting that Caputo's presentation of Gadamer's ideas is inadequate in some aspects.

2. See, for instance, his articles "Über die Planung der Zukunft" (On the Planning of the Future) (1965), "Hermeneutik" (Hermeneutics) (1969), and "Replik zur Hermeneutik und Ideologiekritik" (1971). 
tions of genuine forms of friendship and solidarity in contemporary circumstances. What he aims at is not to attack the existing, perhaps corrupted, forms of social organization, but to point out possible productive forms of interactions which would require some conscious effort for their realization.

This claim conforms with the general attitude of hermeneutics as a practical philosophy which consists of the idea of understanding as "a form of realization of a human social life" (Gadamer, 1971: 289). It means that understanding is not restricted to the experience of texts, works of art, and conversations with other human beings. Understanding is a way to deal with reality that underlies social relationships as well, due to its universality. This universality, however, refers only to the applicability of understanding. In other words, everything can become an object of understanding. From this, however, we cannot conclude that understanding itself emerges anywhere at any occasion. On the contrary, it requires the wakefulness (Wachsamkeit) of an agent. By placing friendship and solidarity in the context of philosophical hermeneutics, Gadamer highlights this universal hermeneutic aspect as a significant part of social relationships. The specificity of Gadamer's interpretation of friendship is to be regarded in a broader and more systematic context than Gadamer's intention to turn philosophical hermeneutics into practical philosophy. He achieves an alternative view on the issue that directly addresses the issues of modern society, precisely due to the synthesis of philosophical hermeneutics with the classical Ancient Greek conception of friendship

In order to accurately understand Gadamer's idea of friendship, it is important to situate this concept properly in the whole context of his thought. There were some attempts to build ethics on the basis of philosophical hermeneutics that appeal to traditional notions of language, play, and dialog. For example, in Gadamer's Ethics of Play: Hermeneutics and the Other (2010), M. Vilhauer tries to ground ethics in Gadamer's concept of play. However, the very idea of play as it is represented in Truth and Method stems from Gadamer's major claim of philosophical hermeneutics as practical philosophy. ${ }^{3}$ In other words, the notion of play is derived from earlier ideas, and if one wants to develop the ethics of play, one has to trace back its origins. In his book Nächstenliebe, Freundschaft, Geselligkeit: Verstehen und Anerkennen Bei Abel, Gadamer und Schleiermacher (1998) (Love to the Neighbor, Friendship, Socialness: Understanding and Recognition in Abel, Gadamer and Schleiermacher), M. Hofer tries to elaborate a notion of friendship that would be in accordance with the basic ideas of philosophical hermeneutics (Hofer, 1998: 119-198). However, he completely ignores Gadamer's views about ethics, practical philosophy, and friendship, and limits the consideration mainly to the ideas expressed in Truth and Meth$o d$. Such approaches distort the way Gadamer's thought developed and, therefore, usually miss the core point. As R. Sullivan states, one can see Gadamer's early writings in the light of his magnum opus Truth and Method, but it will lead to a narrow and inadequate understanding, whereas acknowledging the early Gadamer as a "political theorist" helps to achieve "a simplier and more elegant interpretation" (Sullivan, 1989: 8-10).

3. See Gadamer, 1986 . 
Even at the beginning of his career, Gadamer was occupied with the questions of ethics and politics (see, for instance, his dissertation Platos dialektische Ethik [Plato's Dialectic Ethics] [1931], his articles Praktisches Wissen [Practical Knowledge] [1930], Plato und die Dichter [Plato and the Poets] [1934], and Platos Staat der Erziehung [Plato's Educational State] [1942], to name a few). This interest goes back to his studies of Plato and Aristoteles. However, it was not restricted to a pure theoretical investigation; it was always connected to the question of what the good is. This question should not be seen as a highly abstract metaphysical question, but rather as the one that everyone asks in his or her everyday life.

Friendship and solidarity are parts of a more general conception of practical philosophy. Although there is no systematical text that would present it in an exhaustive way, the idea of hermeneutics as a practical philosophy runs through the entirety of Gadamer's thinking. This inclination exhibits itself most vividly in the 1980 os and the 1990s. Initially, it started with the polemics between Gadamer and Habermas in the 1970s. In a context that was a reaction to Gadamer's Truth and Method, Habermas argues by his emphasizing the significance of authority and tradition, Gadamer fails to adequately understand the reflexive moment of philosophical hermeneutics (Habermas, 1971: 51). Gadamer's answer was that philosophical hermeneutics aims at making one conscious of its own prejudices first of all, but it is impossible to eliminate prejudices, as Habermas claimed. Gadamer argued that one should at least become conscious of it (Gadamer, 1971b).

This reflexive and critical attitude is what Gadamer understands under practical philosophy and not as a specific academic discipline among others. The object of reflection here is the knowledge and skills (das Können) as they are. Philosophical hermeneutics poses the question of the application of certain skills in a transcendental mode, and reveals the condition of the application of the skills. This condition is the reasonableness (Vernunftigkeit) that is intrinsic to every human being.

The claim of practical philosophy as Gadamer states it is the claim for universality: it means that understanding is not a mere scientific method but "a form of realization of a human social life" (Gadamer, 1971a: 289). Thus, he expends the limits of philosophical hermeneutics.

Being a kind of reflection, practical philosophy also contributes to the self-understanding of an individual. Regarded from the perspective of social interactions, it means a very specific thing for Gadamer. This is social consciousness or conscious awareness of an individual, which signifies that his or her actions can be meaningful only in the context of a concrete community. Hence, they are meaningful, they can be judged as good or bad, or as appropriate or not. There is no objective value prior to community. However, this does not mean sheer relativism. The hermeneutical claim for universality presupposes that one acknowledges not the particular content of the morals that remain unchanged, but the fact that human beings are reasonable, and therefore, moral creatures.

These are basic premises of practical philosophy that were expressed in full, though detached from the philosophical-historical analysis of the 1980s. Before this period, one can find a mixture of contemplations concerning the subject matter together with the 
examination of textual evidence. However, it is to be noted once again that the practical bias of philosophical hermeneutics originally stems from the genuine interest in practical philosophy, and not the other way around.

Even if one admits to the influence practical philosophy had on the origins of Gadamer's thinking, it does not mean that he could be labeled with a title of an ethical or a political philosopher or theorist, as R. Sullivan does, for example. Apart from the fact that such labeling is rather useless to understand Gadamer's project, Gadamer had himself consciously tried to avoid theoretical one-sidedness, as well as abstraction and labeling. This attitude had an immediate effect on the way Gadamer presented his thoughts.

In the pursuit of an integral presentation of Gadamer's ideas about practical philosophy and the problem of friendship in particular, one should take the following condition into consideration. Gadamer's late writings often have the character of a dialogue, be it a response to a social discussion relevant at that time, or a reaction to a book or an event, or a public speech. It means that an immediate life-context served as an occasion to touch upon some philosophical issues. This is the case with the two texts in which he addresses the question of friendship directly. The first, published in 1985 as an article entitled "Friendship and Self-Knowledge: Reflections on the Role of Friendship in Greek Ethics" was presented as his inaugural speech at the University of Marburg in 1928. The article represents an extended version of the speech. The second, titled "Friendship and Solidarity" (1999), aims at discussing the role of friendship and solidarity in modern society under the conditions of a new social order and habits of coexistence. Both texts treat the topic in various ways, from the point of view of the history of philosophy, from the current perspective, and from a theoretical angle.

Despite the essay-like character of reflections and the lack of systematic approach, these two texts allow the selection of a number of significant aspects, and to form a coherent and detailed notion of friendship according to Gadamer. The features to regard are the structure of friendship, its meaning in the context of communal human life, and its essence.

\section{Friendship as a Reciprocal Relation}

One of the problems Gadamer wants to answer in his discussion of friendship is the problem of the possibility and grounds of social interaction. As a philosopher, he is restrained to the philosophical scope and does not deal with sociological theories. However, he cannot find a sufficient explanation in the philosophical theories of his time. When the paper was first presented in 1928, his research context was defined by Kant's deontological ethics and phenomenological ethics of value in Scheler's version, as well as neo-Kantian transcendental idealism, of which he was quite critical. He notes that the more-or-less common point of departure of all three theories was self-consciousness. As opposed to both phenomenology and neo-Kantianism, he chose to follow what he calls "Heidegger's way," and to resign from the idea of self-consciousness as the starting point for philosophical considerations (Gadamer, 1999: 129). It may not be quite clear from first sight in what 
way Heidegger can be helpful for the formulation of a theory of social interaction, since it was never his strong point or point of interest. What is important for Gadamer is not the content or some specific method, but Heidegger's general philosophical attitude (Gadamer, 1987: 187-188). First of all, according to Gadamer, Heidegger stressed the necessity to read the Greeks anew, which was what Gadamer then pursued during the 20's and 30's. Secondly, he was influenced by Heidegger's idea of the hermeneutics of facticity, where the preference is given to the fore-structures of understanding, and not to the consciousness and to the "situatedness" of a human being in each specific time (jeweilig) and context of one's life. It is the clue to understanding Gadamer's notion of ethics. It is likewise important to him that Aristotle grounds practical philosophy in the concrete moral and political experience and the way they are expressed, and not in metaphysics (Gadamer, 1999: 132). Gadamer takes the same position in his view on practical philosophy. ${ }^{4}$

In Aristotle's understanding of ethics, politics, and friendship, it is common that it is not "the business of the one or the other." The acknowledgement of this fact is the feature of practical philosophy and an aspect that makes it different from the modern philosophy of self-consciousness. Thus, Gadamer declines the latter position because it cannot provide any plausible explanation of "the ontological constitution of society" (Gadamer, 1999: 131). For him, the Greek practical philosophy might play a role of "a paradigm for the critique of subjectivity (Subjektivitätsdenken)." The alternative to subjectivity is "the structure of self-relatedness." Thus, for instance, self-love and self-sufficiency are of particular importance for the understanding of friendship.

In Gadamer's description, one can differentiate three of types of relations. The first is self-love, or a relation to oneself or between parts of the soul which is the precondition of friendship. The second type is the reciprocity (Gegenseitigkeit), or a relation between persons based on mutual utility, pleasantness, or interest. The third type is life together (Zusammenleben), the highest type of organization of communal human life.

The term "philautia" refers to the concept of self-love, and is an ambiguous term in the Greek tradition. On the one hand, it was used as a negative attribute to characterize someone who is too enclosed or immersed in one's own self. For Aristotle, however, self-love acquires a positive connotation since it makes one close to the ideal of self-sufficiency, or autarchy of a divine pattern. Self-love allows for the resolution of the conflict between reason and passions, and to achieve the unity of two parts of the soul, the rational and the irrational (Gadamer, 1999: 135-136). Thus, this experience of reconciliation is what one first experiences in oneself and can be transferred later in the sphere of relationships with others. It would be problematic to live with others if one is not united with oneself, leading Gadamer to state "friendship must exist first and foremost with oneself" (Gadamer, 2009: 8). It is only under this condition a person can be united with others.

If one then moves to the interpersonal level, there are two further, distinct kinds of relations. It is possible to characterize them as inauthentic and authentic. As for Gadamer, there is the authentic that is more preferable and has positive outcomes for the well-being

4. M. Kelly, in his article "Gadamer and Philosophical Ethics", gives a detailed description of Gadamer's ethical project that includes both Aristotelian and Kantian elements (Kelly, 1988). 
for the community, whereas the inauthentic remains deficient in some way. The basic structural feature of any kind of friendship is reciprocity (Gegenseitigkeit) (Gadamer, 1999: 134). However, it remains that one has to differentiate between friendship and mere friendliness. The latter can be reciprocal, but still lacks a kind of openness towards the other. It is not enough to have sympathy or good will towards one another to establish friendship. Thus, there can be a reciprocal relation between human beings based on the mutual good will, but it will still not be friendship.

The other significant feature of friendship is openness (Gadamer, 1999: 134). The actors of friendship are no longer concealed from each other. There is one important consequence that follows from this claim for openness, which is that it leads to the recognition of the "other" as the "other," or as Gadamer puts it, "we grant to one another our being as Other" (Gadamer, 2009: 9). Thus, the Hegelian idea of striving for the recognition is realized for Gadamer when friendship is the recognition of equals. It allows otherness to be retained together with the experience of unity. In order to be united, one does not necessarily need to be unanimous. The ground of unity lies not in the similarity of opinions, but in the initial intention to be united. Thus, this third superior kind of relation is primarily characterized by the existence of the bond (Verbundenheit) that leads to the establishment of a life together (Zusammenleben) (Gadamer, 1999: 134).

Now, one could ask about the status or essence of this bond. Does Gadamer mean something similar to the social contract? The answer would be no, since in this case, Gadamer's strategy is that of phenomenology. He traces back to the possibility of creating bonds to some initial experience, and his example is the experience of the homeland. According to Gadamer, a homeland is something that could be grasped as connection itself (Gadamer, 2009: 7). Our experience of a homeland is the experience of an attachment of the "genuine" kind, when we perceive the scenery as unconditionally beautiful, when we already belong to the community, and are solidary and joint. ${ }^{5}$ Starting from this initial experience, we can then interact with others on the same basis.

To sum up, since friendship is understood as a relation, we can discern three various types of relations that Gadamer introduces. He starts with intra-personal relation of selflove that serves as a precondition of friendship. Self-love, or philautia, can than lead to friendship, or philia. Furthermore, there is a difference between the two kinds of interpersonal relationships that are necessary reciprocal. Whereas friendliness is a reciprocity

5. In his 1945 article "The Homecomer," Alfred Schütz analyzed this type of social bond, addressing the problem of the process of adaptation by soldiers returning home from war. The author introduces the concept of the primordial we-relation which is based on accessibility of a certain sector of the outer world (space) and the continuation of this common life (time) as the grounding point for any social relationship. The problem of the soldier at war consists of the impossibility to share everyday experiences with the members of the community that remained at home. Thus, even if the latter are informed by newspapers or movie reports about life at front, they cannot share this experience in full. Schuetz diagnoses a "separation" between the home-comer and his close circle that is hard to remove and to "re-establish the disrupted we-relation" (Schütz, 1945: 373-374). One can assume that a similar separation may well occur to people who do not participate directly in warfare but their daily lives are still significantly influenced by the war event. Thus there is no place for a habitual continuity of relationships in space and time. As a result average citizens also face the problem of adaptation, not only home-comers. 
that requires good will but lacks openness, friendship is reciprocal, and at the same time, it is expected that the persons are opened towards each other. This means that they are ready to share life together but still retain an independence of opinions, interests, and life goals.

\section{Friendship as Solidarity}

As already mentioned, the question of friendship for Gadamer is not a matter of theoretical consideration. He appeals to the Greeks not only as a source of knowledge, but also as an example of how particular ideas were brought to life. If the stance on the problem in the 1985 article "Friendship and Self-Knowledge" was more general, then he directly addresses the problems of today and brings his own conception of friendship with the prevailing ideas of solidarity together in the article "Friendship and Solidarity." His starting point is the modern mass society in which he diagnoses the lack of "natural" solidarity. Gadamer's speculations about friendship are not in a broad historic-philosophical context, but in specific circumstances. According to him, these circumstances are deficient. $\mathrm{He}$ is critical about modern society which he calls a society of "anonymous responsibility," after K. Jaspers (Gadamer, 2009: 3). It means that social bonds in modernity are created on alternative grounds as compared to earlier periods. This is why there is still solidarity and, therefore, responsibility, but this solidarity is an "avowed" (erklärt) one.

Gadamer admits that there is a certain tension between the concepts of friendship and solidarity in modern thought. His goal is to prove that these two concepts are not opposite but, on the contrary, inseparable (Gadamer, 2009: 5). In order to do this, he first shows the inconsistency of the modern representation of solidarity, and then offers his own understanding. It is worthy to note that Gadamer's analysis of solidarity does not take pre-existing theories of solidarity into consideration, such as Durkheim's differentiation between mechanical and organic solidarity, or Tönnies' ideal types of community and society. Furthermore, the way Gadamer interprets solidarity is hardly compatible with these conceptions. If Durkheim and Tönnies both emphasize the role of the interpersonal source of solidarity, be it the social common consciousness in case of the former or a special type of common will in the case of the latter, Gadamer ascribes solidarity to individuals. Moreover, he does not tie solidarity to a particular, more preferable social order, but claims that solidarity can emerge in different types of communities, traditional and modern, and based on personal, or mediated and indirect interactions. Gadamer's concept of solidarity stresses its conscious character, and, at the same time, the fact that solidarity is an event, a kind of experience that is supposed to seize the participants.

Gadamer contrasts natural and avowed solidarity, which differ in the way they emerge. Natural solidarity is something one "feels." As an example, Gadamer recalls the situation during the war period, when a significant transformation occurred in the way people related to each other. Under the circumstances of the bombing of city-dwellers who were otherwise strangers, the normally anonymous inhabitants of a big modern city "were awoken to life" (Gadamer, 2009: 10). To express it in a stricter way, they were all united 
by the common goal of survival, aware that that this kind of unity emerged from the common need. Thus, natural solidarity makes one recognize the right of the other to be the other. The most radical example of this is when every person is willing to risk their own life, and then the participants immediately acknowledge that each and every one of their counterparts has the same pretension as they did. In this situation, if a danger or a constraint is perceived as shared, than solidarity emerges. In other words, to be able to act in accordance with others on a natural basis, an individual must admit that others have the same claims and each person is in the same situation in which the individual's right of these claims is challenged. As G. Warnke correctly admits, only friendship allows to see the others precisely as others, whereas "Under the conditions of mass society we fail to be others to one another because we are undifferentiated parts of a mass" (Warnke, 2012: 11).

As opposed to natural solidarity, an avowed solidarity is not felt, but "declared." One can declare solidarity, binding themselves to an external obligation. Although it originates from an internal commitment, it is not the power of one's intention that forces one to stay true to what has been promised, but rather this external duty from the moment it has been expressed. Gadamer asks whether "not too many things in which we could really recognize (wiedererkennen) ourselves are being withheld (vorenthalten) from us?" (Gadamer, 2009: 10), meaning that the mechanisms in mass society governing this society are created outside of it with the help of statistics and expert evaluation. The citizens are no more responsible for developing bonds.

The origin of the word "solidarity" can be traced back to its roots in the Latin word "solidum," which means "solid," or "hard." In German, it also refers to "Sold," which means "salary." From this, Gadamer concludes that the modern understanding of solidarity rests upon the idea of constancy. Like a payment that is made not using counterfeit money and retaining its value in any circumstances, it is also expected that solidarity ensures "a sterling and reliable inseparability" (Gadamer, 2009: 11). That is to say, an individual will remain loyal to what he or she has joined, but in order to be capable to remain "inseparable," one has to abandon one's own interests and preferences. Using this logic, avowed solidarity is more an artificial state in which one limits his own will for the sake of the common will. This is also why such solidarity has to be enunciated in order to persist.

Gadamer finds this strategy of the declaring of solidarity erroneous, as it leaves no place for the needs of an individual. For him, the basic principle of a community would be a mutual recognition and reconciliation of common and individual interests that is realized through a constant elaboration of ways to act. This is why he claims that "authentic solidarity must be conscious" (Gadamer, 2009: 11). By this, he means that conscious awareness presupposes that every member of a community makes a conscious decision when he or she chooses to participate in a communal action. If this condition is fulfilled by every member of the community, then the communal action itself will be realized consciously, and not merely on the grounds of the earlier declared agreement. Thus, this solidarity will regularly receive a new confirmation, and remains something that can be lived through and felt. For Gadamer, the ultimate source of solidarity lies in individuals: 
he writes that "real solidarity depends on the individuals who have avowed themselves to it and stood up for it" (Gadamer, 2009: 11).

Such an interpretation of solidarity brings it closer to the notion of friendship. Gadamer draws a line from solidarity via camaraderie (Kameradschaft) to friendship to emphasize the commonality of the two notions. Both friendship and solidarity depend on good will (Gadamer, 2009: 12), and could not be established from within. On the contrary, they require effort and engagement from those who strive to create bonds and, at the same time, to allow the other to pursue their own goals.

Gadamer does not pay any special attention to delimiting friendship and solidarity. There are three ways of defining the correlation between friendship and solidarity that can be deduced from his discussion: (1) friendship and solidarity are the same; (2) friendship is opposed to solidarity; (3) friendship and solidarity have a common ground, but serve to describe social interaction on different levels. The evidence for the first interpretation consists in the fact that Gadamer himself suggests the Greek word "philia," which is normally translated as "friendship," be translated with the term "solidarity" (Gadamer, 2009: 12). This indicates that these two notions are closely connected for Gadamer. However, he does not go so far as to declare that they are one and the same, since there are still differences between them. The second possibility would be to say that friendship, as a kind of immediate and confidential relationship without evident practical purpose, is opposite to solidarity which originates as a relationship between strangers and serves to fulfill everyday needs. If one adheres to the understanding of solidarity suggested by Gadamer as a description of the modern state of affairs, then, indeed, solidarity would be contrary to how Gadamer represents friendship. The most plausible explanation would be to say that friendship and solidarity initially share common premises, but are used to characterize different types of interpersonal interaction. ${ }^{6}$ Thus, the notion of solidarity is attributed to characterize social bonds in larger groups, and as Gadamer sees it, becomes especially important under the condition of modern mass society. While the notion of friendship is primordial, this delivers a general idea of what counts as an authentic interpersonal relationship.

\section{Friendship as Increase in Being}

Gadamer's elaboration of the notion of friendship is multidimensional. It includes a historic-philosophical stance as well as an applied approach. It contains a descriptive aspect together with a prescriptive touch. It addresses epistemological issues and, at the same time, aims at practical tasks. As it has been noted earlier, Gadamer's considerations are initially conceived as a part of practical philosophy, called "practical" not because of the subject it deals with, but because of the contribution to the communal life and the impact it is supposed to have. Therefore, Gadamer does not confine himself to a mere theoretical

6. D. Walhof, in his article "Friendship, Otherness, and Gadamer's Politics of Solidarity," comes to a similar conclusion, drawing on Gadamer's difference between friendship and solidarity precisely on the basis of the scope of interpersonal interaction (Walhof, 2006: 584). 
analysis, but also sets up a kind of normative horizon. It would be an exaggeration to say that he introduces a deontological ethical system; his claim is far more modest. However, one can speak of a certain teleology of friendship. That is why, apart from the structural analysis of friendship as presented in the first part of this article, Gadamer's discussions allow for the regarding of the concept of friendship in an anthropological and teleological perspective, as compared to previous structural analyses.

As it has already been partly shown, Gadamer gives a particular preference to one kind of relation, namely friendship, as opposed to simple friendliness. Now, among various types of friendship that is based on competition between young boys or older men, or friendship between family partners, there is one superior type which Gadamer calls life friendship (Lebensfreundschaft). He adopts Aristotle's taxonomy of friendship which presupposes three species of friendship: the one based on utility or profit, the other based on pleasure, and the third and the highest one based on excellence or virtue (Aristotle, 2014: 163-164).

There is a strict, unsurpassable qualitative limit between the first two species taken together and the third species of friendship. Only friendship based on excellence fulfills it, but perhaps it is better to say strives for and is capable of fulfilling the idea of friendship. The other two kinds are only "analogous" to the life friendship (Gadamer, 1999: 133). Here, analogous means that other kinds of relations based on mutual use or pleasure can be interpreted by appealing to the example of the friendship of excellence.

In Aristotle's works, this confusion is cleared up with the example of soul and body, in which a "medical" (or "healthy" in an alternative translation) body is analogous to a "medical" soul. Both participate in the universal idea of "medical" (Aristotle, 2014: 164). Then, the two first types are also called friendships, since true friendship is partially present in them. However, at the same time, they lack the opportunity to participate in this "perfection" to be comparable or equal to the friendship of excellence. Although it may seem that the difference between the three kinds is quantitative, it turns out that the perfection of the third type, the excellence, makes it qualitatively different as well.

The friendship of virtue is grounded on the mutual excellence of two friends. It means that the goal of this relationship, although it includes reciprocal pleasure and also profit, nevertheless surpasses the limits of what is good in specific life circumstances. and strives to the good in general. The distinctive feature of life friendship, as Gadamer represents it, is its fundamental incompleteness (Gadamer, 2009: 10). ${ }^{7}$ There is a certain anthropological premise behind this claim. Just like Aristotle, Gadamer places the human being between god and animal. The latter does not experience a conflict between needs, urge, and rational choice. A human being, on the contrary, is challenged with the necessity of making a decision, he is initially incomplete and has to fill in this lack. As compared to a god, a human being is unable to achieve the divine completeness or autarchy on his

7. B. Bryan, in his detailed article "Approaching Others: Aristotle on Friendship's Possibility," defends the idea that friendship as something "unfinished" was already proper to Aristotle himself. He argues that friendship, for Aristotle, exists only as possibility and never as an actuality (Bryan, 2009). It is partly in keeping with Gadamer's own understanding of friendship. 
own. Some individuals can approach this state, others can be very far from it, but an isolated individual can never succeed in acquiring it alone. According to Aristotle, a friend is someone who can better understand a person that that person themselves. Gadamer explains it by appealing to the fact that a human being usually tends to have self-illusions (Gadamer, 1999: 137). Thus, the claim for self-knowledge becomes a difficult task that is never to be fully achieved.

A friend is supposed to be someone who helps to eliminate this lack. For Gadamer, friendship has a twofold or dialectical structure. On the one hand, it presupposes that one is brought to "being at one with another" (des anderen inne ist) ${ }^{8}$ (Gadamer, 1999: 137), while, on the other hand, it allows to "discern" or to preserve and to feel one's own self (das eigene Selbst ist mitgewahrt und mitgefühlt) (Gadamer, 1999: 137). This dynamic is structurally similar to the process of "understanding" as it is depicted in philosophical hermeneutics. Through the understanding of a text or a work of art, one acquires access to the tradition, and becomes part of it. At the same time, every understanding is reflective and allows one to understand himself. In other words, in order to obtain an agreement with the other, one has to become conscious of similarities there are between the two. By doing this, one better understands oneself.

Not only can such relations never be fully completed because of this dialectical or oscillating movement, but it also has a specific type of presence. The other characteristic feature of friendship is the accession or increase in being (Zuwachs an Sein). Gadamer uses this concept in Truth and Method when he describes the peculiar way of being of a work of art distinguishes it from a mere sign or a symbol. If a picture is not simply a copy, than it represents the original, and at the same time, presents itself (Gadamer, 2004: 134), whereas a sign is "pure indication" (Verweisung) and a symbol is "pure substitution" (Stellvertreter) (Gadamer, 2004: 145). It means that a sign only serves to point to a being outside of itself. Thus, a sign on its own as an independent being should dissolve. On the contrary, a symbol represents something that is not given to sense perception, like a political or religious unity of people, for instance. However, the content of a symbol is always schematic; it is not due to its inherent content that a symbol can serve as a substitution (Gadamer, 2004: 148). Thus, it would be just to claim that the matter performs a function of an intermediary and is perceived as secondary for both the sign and the symbol. In the case of a work of art, it is impossible to break the connection between what is "being represented" and what "represents," and, therefore, between representation and presentation. It is only due to presentation of a particular subject that representation

8. It is worth quoting the entire passage here: "Die energeia, in der eudaimonia und philia bestehen, ist nicht so sehr in dem Sinne Tätigkeit; dass es dabei auf ein ergon ankäme, als vielmehr auf den Vollzug der eigenen Lebendigkeit selbst. Energeia mag immer beides enthalten, Hingabe an den anderen oder das andere und Hingabe an den Vollzug selbst. Aber auch dann bleibt das Wesen des Lebensvollzuges, dass man des anderen inne ist, der Andersheit der Dinge wie der anderen Menschen“ (Gadamer, 1991: 403-404). It is then translated as follows: "The energeia, consisting of eudaimonia and philia, is not really activity in the sense of depending on an ergon, but rather of realizing its own vitality. Energeia can always involve both: devotion to others or another and devotion to the realization itself. But even then the essence of the realization of life is still being at one with another, whether the otherness of things or other people" (Gadamer, 1999: 138). 
becomes possible. Since such a presentation does not immediately point to some external being but adds something to this being that was not already present in it, a perceiver is encouraged to actively engage at the same time with what is being presented. It does not serve to arrange a connection between a perceiving subject and what already exists but is itself a contribution, or an addition of something entirely new to being. Thus, a work of art leads to an increase in being, because it suggests such forms of interaction that would enforce an accession. As Gadamer states, "What comes into being in it [a portrait] is not contained in what acquaintances can already see in the person portrayed" (Gadamer, 2004: 142).

Gadamer uses the same term, Zuwachs an Sein, or an increase in being, to characterize friendship. In the case of the work of art, the possibility of the increase is connected to a specific possibility of this work to overcome the boundaries of the original. In friendship, it is the friend who allows one to expand one's own limits. As has already been mentioned, Gadamer emphasizes the finite essence of a human being and the fact that he or she alone will never be able to achieve the divine ideal of autarchy. If an individual acknowledges this fact, he is compelled to seek the possibilities of connections with others. It becomes possible to prevail over this initial condition of finiteness by means of a reciprocal relationship in which the two participants act as mirrors to each other

Gadamer connects friendship with the idea of "realization of vitality" (Lebendigkeit) (Gadamer, 1999: 138). For him, friendship, as well as other ways of social interaction and even broader interactions in general such as, for instance, the experience of a work of art, is a kind of practice in which the process and the product remain indiscernible. They contribute to the increase in being not by providing a separated embodied output but by transforming the reality. The final effect of friendship consists in establishing a social connection and creating the reality which was previously nonexistent. It is described as an encounter which differs from a demand, a duty, or a command. One meets another person (ein leibhaftes Gegenüber), and the way to interact with her or him is to increase trust and devotion. In the interaction, Gadamer sees "the full stream of self-forming commonalities" (Strom sich bildender Gemeinsamkeiten). For him, this practice underlies "a real embedding in the texture of communal human life" (eine reale Einbettung in das Gefüge der miteinander lebenden Menschen) (Gadamer, 1999: 139).

\section{Conclusion}

The notions of friendship and solidarity are parts of Gadamer's conception of practical philosophy. Although it does not receive a systematic elaboration, there is still strong evidence for the claim that Gadamer's project of philosophical hermeneutics was always concerned with the ethical dimension of philosophy as well as the epistemological dimension. In his discussion of friendship and solidarity Gadamer synthesizes Greek thought, Heidegger's early philosophy, and his own ideas to formulate a concept of friendship that would address the issues of modern society. He sees friendship as a structure of a certain meaningful interpersonal relationship. It is significant for a formation of an indi- 
vidual person, but also serves as grounds for the emergence of social bonds. Gadamer's approach is deliberately interpersonal as opposed to those who try to explain intersubjectivity with the help of structures of consciousness. Furthermore, it is seen as a relationship that contains a certain ideal of human realization which can never be reached but, nevertheless, serves as a horizon for moral orientation. Although Gadamer emphasizes the role of tradition, it is important to identify the role he ascribes to it. Tradition serves as a precondition or a fore-structure of possible future bonds. It is not considered as an invariable substrate that carries random and mutable forms of social interaction. There is a significant difference between context and essence. Tradition functions as the former, whereas there is no place for a classical notion of essence in philosophical hermeneutics. On the contrary, its main claim is to involve and participate in relations that did not exist before this engagement, and to bring the being itself into being. Being is understood here not metaphysically, but rather as facticity in Heidegger's terms, or as ethos, the constellation of morals of a certain society, as Gadamer himself defines it. Despite the fact that the true friendship will always remain incomplete, it contributes to the increase in being through establishing and experiencing unique social connections. Gadamer's message is not normative in character but rather performative. His aim is to discuss certain aspects of human common life, making his own contribution to what he calls the texture of this life, and perhaps encouraging others to follow this strategy.

\section{References}

Aristotle (2014) Aristotle’s Ethics: The Complete Writings, Princeton: Princeton University Press.

Caputo J. (2002) Good Will and the Hermeneutics of Friendship: Gadamer and Derrida. Philosophy and Social Criticism, vol. 28, no 5, pp. 512-522.

Gadamer H.-G. (1971) Replik zu Hermeneutik und Ideologiekritik. Hermeneutik als Ideologiekritik, Frankfurt am Main: Suhrkamp, S. 283-317.

Gadamer H.-G. (1971) Rhetorik, Hermeneutik und Ideologiekritik: Metakritische Erörterungen zu "Wahrheit und Methode". Hermeneutik als Ideologiekritik, Frankfurt am Main: Suhrkamp, S. 57-82.

Gadamer H.-G. (1986) Hermeneutik als Theoretische und Praktische Aufgabe. Gesammelte Werke, Band 2, Tübingen: Mohr, S. 301-319.

Gadamer H.-G. (1987) Martin Heidegger 75 Jahre Alt. Gesammelte Werke, Band 3, Tübingen: Mohr, S. 186-196.

Gadamer H.-G. (1991) Freundschaft und Selbsterkenntnis: Zur Rolle der Freundschaft in der griechischen Ethik. Gesammelte Werke, Band 7, Tübingen: Mohr Siebeck, S. 396406.

Gadamer H.-G. (1999) Friendship and Self-Knowledge: Reflections on the Role of Friendship in Greek Ethics. Hermeneutics, Religion, and Ethics, New Haven: Yale University Press, pp. 128-141. 
Gadamer H.-G. (2000) Freundschaft und Solidarität. Hermeneutische Entwürfe: Vorträge und Aufsätze, Tübingen: Mohr Siebeck, S. 56-68.

Gadamer H.-G. (2004) Truth and Method, London: Continuum.

Gadamer H.-G. (2009) Friendship and Solidarity. Research in Phenomenology, vol. 39, no 1, pp. $3^{-12 .}$

Habermas J. (1971) Zu Gadamer's "Wahrheit und Methode”. Hermeneutik als Ideologiekritik, Frankfurt am Main: Suhrkamp, S. 45-56.

Hofer M. (1998) Freundschaft (Gadamer). Nächstenliebe, Freundschaft, Geselligkeit: Verstehen und Anerkennen bei Abel, Gadamer und Schleiermacher, München: Wilhelm Fink, S. 119-198.

Kelly M. (1988) Gadamer and Philosophical Ethics. Man and World, vol. 21, no 3, pp. 327346.

Schütz A. (1945) The Homecomer. American Journal of Sociology, vol. 50, no 5, pp. 369376.

Sullivan R. R. (1989) Political Hermeneutics: The Early Thinking of Hans-Georg Gadamer, University Park: Pennsylvania State University Press.

Vilhauer M. (2010) Gadamer's Ethics of Play: Hermeneutics and the Other, Lanham: Lexington Books.

Walhof D.R. (2006) Friendship, Otherness, and Gadamer's Politics of Solidarity. Political Theory, vol. 34, no 5, pp. 569-593.

Warnke G. (2012) Solidarity and Tradition in Gadamer's Hermeneutics. History and Theory, vol. 5, no 4, pp. 6-22.

\title{
Гадамер о дружбе и солидарности: прирост бытия в совместной человеческой жизни
}

\author{
Александра Макурова \\ Аспирантка Аспирантской школы по философским наукам Национального исследовательского \\ университета «Высшая школа экономики» \\ ул. Мясницкая, д. 20, г. Москва, Российская Федерация 101000 \\ E-mail: alexandra.makurova@gmail.com
}

В статье рассматривается понятие дружбы в статьях Х.-Г. Гадамера. Идея дружбы является частью его концепции практической философии. Отправной точкой его размышлений является греческая философия, в частности, взгляды Платона и Аристотеля на феномен дружбы. Гадамер дополняет концепцию дружбы идеями, которые традиционно связываются с философской герменевтикой, а именно трансформативный аспект понимания, взаимосвязь понимания и самопонимания. Понятие дружбы рассматривается Гадамером в контексте актуальных проблем современного сообщества, которое он оценивает, как общество анонимной ответственности. Предлагаемое им понимание дружбы является вкладом в современную дискуссию о дружбе. Он противопоставляет свое представление тем философским школам, которые в качестве возможного источника социальности видят 
самосознание. Гадамер, напротив, подчеркивает необходимость межличностного взаимного отношения, которое становится основанием любых социальных связей. Дружба в понимании Гадамера имеет значение не только в рамках общества или сообщества, но обладает также характерной телеологией. Значение дружбы состоит в том, что она, как и вообще всякий аутентичный опыт, по Гадамеру, будь то опыт понимания, взаимодействия с произведением искусства, или то, что Гадамер в поздних работах понимает под практической философией, приводит к приросту бытия. Дружба сама по себе является некоторым особенным видом практики, в котором невозможно различить процесс и результат этого процесса.

Ключевые слова: Гадамер, философская герменевтика, дружба, солидарность, прирост бытия, понимание, практическая философия 